\title{
New records of mononchid nematodes from forests in the Slovak Republic
}

\author{
M. LIŠKOVÁ \\ Parasitological Institute, Slovak Academy of Sciences, Hlinkova 3, 04001 Košice, Slovak Republic, \\ E-mail: liskova@saske.sk
}

\begin{abstract}
Summary
Three mononchid nematode species new for the Slovak Republic were recorded in forest ecosystems. In regularlyflooded forests with Fraxineto - Salicetum vegetation, the species Mylonchulus andrassyi and Tigronchoides ginglymodontus were recorded; in soil with the Querceto Carpinetum forest type, the species Miconchus hopperi was observed. Comments on the morphometrical characteristics and ecology of the recorded species are presented here.
\end{abstract}

Key words: Mononchida; Miconchus hopperi; Mylonchulus andrassyi; Tigronchoides ginglymodontus; forest; Slovakia

During the investigation of nematode communities of forest ecosystems, three mononchid species new for the fauna of Slovakia were recorded. They are Miconchus hopperi Mulvey, 1962, Mylonchulus andrassyi Loof, 1993 and Tigronchoides ginglymodontus (Mulvey, 1961) Andrássy, 1993.

The nematodes were recovered from soil samples by the sieving and decanting technique using a sieve of $80 \mu \mathrm{m}$ with final extraction using a Baermann funnel. They were heat-killed, fixed in FAA, transferred to anhydrous glycerine and mounted permanently on microscope slides. Representative specimens were deposited in the nematode collection at the Parasitological Institute of SAS, Košice, Slovak Republic.

Miconchus hopperi Mulvey, 1962 (Fig. 1. A-C)

Measurement and description

Female (1): $\mathrm{L}=3.00 \mathrm{~mm} ; \mathrm{a}=42.9 ; \mathrm{b}=4.7 ; \mathrm{c}=9.4 ; \mathrm{c}^{\prime}=$ $6.6 ; \mathrm{V}=66.8 \%$; buccal cavity $59 \times 36 \mu \mathrm{m}$; tail length $=$ $316 \mu \mathrm{m}$.

Males (2): $\mathrm{L}=2.5,2.6 \mathrm{~mm} ; \mathrm{a}=30,32 ; \mathrm{b}=4.7,5.0 ; \mathrm{c}=$

$11.6,12.4 ; c^{\prime}=3.6,4.5 ;$ buccal cavity $=50 \times 39,52 \times 36 \mu \mathrm{m}$; spicules length $=92.9,96.0 \mu \mathrm{m} ; \quad$ supplements $=12,13$; tail length $=200,224 \mu \mathrm{m}$.

The morphometrical characteristics of the Slovak specimens closely concur with the original description by Mulvey (1962) from the U.S.A and the description by Popovici (1990) from Romania.

Female is ventrally arcuated upon fixation; cuticule smooth; lip region with distinct labial papillae, lips $20 \mu \mathrm{m}$ high and $60 \mu \mathrm{m}$ wide, set off.. Buccal cavity elongate, moderately chitinised, teeth fairly large, nearly of equal size, dorsal tooth apex $20 \mu \mathrm{m}$ or $34 \%$ from base of buccal cavity. Oesophagus $644 \mu \mathrm{m}$ long. Vulva transverse, reproductive tract double, reflected, egg 112 × $25 \mu \mathrm{m}$. Diameter of body at anal level $48 \mu \mathrm{m}$. Tail conoid, arcuate, strongly tapering with acutely rounded terminus; caudal glands and spinneret absent. In contrast to the original description, our female specimen is characterised by a more tapering end of the tail.

Males of smaller body length in comparison to female. The form of labia, buccal cavity and tail similar to those of female, but the posterior part of body is extremely curved with almost reversed tail. The spinneret and caudal glands absent. Diameter of body at level of anus $56,62 \mu \mathrm{m}$. The gubernaculum of $20,23 \mu \mathrm{m}$ and lateral accessory pieces of $16 \mu \mathrm{m}$ long.

\section{Locality and plant association}

The species was recorded at the locality of Podčičva, orographic unit Beskydské predhorie promontory of north eastern region of Slovakia. The sampling site is characterised by Querceto - Carpinetum forest with undergrowth mostly of Rubus caesius and Asperula sp., by heavy clayloamy forest soil, soil type Cambisol derived from Carpathian flysh.

This rare species is known from California, where it was originally described from the rhizosphere of Pinetum forest (Mulvey, 1962); in Europe it is known from Romania, 

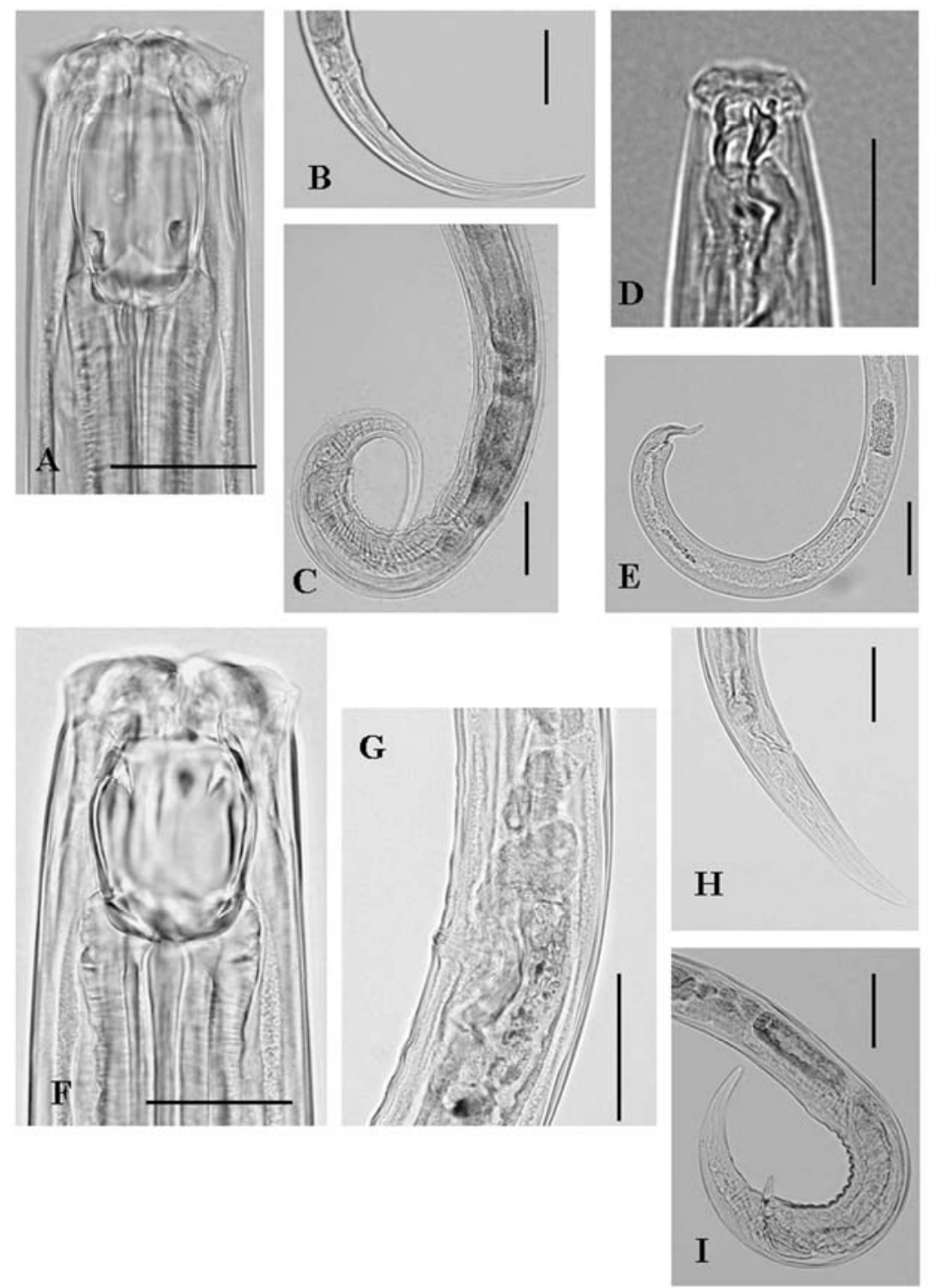

Fig. 1. Miconchus hopperi Mulvey, 1962. A: Female head region; B: Female tail; C: Male tail. Mylonchulus andrassyi Loof, 1993. D: Female head region; E: Vulva and posterior region. Tigronchoides ginglymodontus (Mulvey, 1961) Andrássy, 1993. F: Female head region; G: Vaginal region; H: Female tail; I: Male posterior region;

(Scale bars: $\mathrm{D}=25 \mu \mathrm{m} ; \mathrm{A}, \mathrm{F}=40 \mu \mathrm{m} ; \mathrm{B}, \mathrm{C}=75 \mu \mathrm{m} ; \mathrm{E}, \mathrm{G}, \mathrm{H}, \mathrm{I}=100 \mu \mathrm{m}$ )

where it occurs in the soil of Fagetum and Piceetum forest, meadow, pasture and dwarf shrubs (Popovici, 1990) and in the Ukraine (Bongers, 2004).

\section{Mylonchulus andrassyi Loof, 1993 (Fig. 1. D - E)}

\section{Measurement and description}

Females (2): $\mathrm{L}=1.03,1.10 \mathrm{~mm} ; \mathrm{a}=26.3,32.2 ; \mathrm{b}=3.7 ; \mathrm{c}$ $=22.4,27.6 ; \mathrm{c}^{\prime}=1.8,2.3,27.6 ; \mathrm{V}=71.0,75.2 \%$.

Males absent.

The morphometrics of the females closely concur with the description of the female from Austria (Loof, 1993), from which it differs by larger body width $(\mathrm{a}=26.3,32.2$ vs. 39) and by longer uterine sac ( 80 and $112 \mu \mathrm{m}$ vs. $32 \mu \mathrm{m})$. The morphometrics of Slovak females correspond well to those listed in The Key to Species of Mylonchulus published by Andrássy (1992) as well. They were characterised by an arcuated C-form of the body after fixation, lip region of one female of $20 \mu \mathrm{m}$ wide and $6 \mu \mathrm{m}$ high, separated, buccal cavity $20 \times 10 \mu \mathrm{m}$, dorsal teeth apex $16 \mu \mathrm{m}$, or $81 \%$ from the base of buccal cavity, 5 transverse rows of denticles. The second female showed a deformed head region. Maximal body width of $40,42 \mu \mathrm{m}$, body width at anal level of 21 and $22 \mu \mathrm{m}$. Reproductive system monodelphic, vulva with gentle but distinct sclerotised pieces, no vulval papillae present. Post uterine sac $80,112 \mu \mathrm{m}$ long. One egg $52 \times 20,84 \times 30 \mu \mathrm{m}$. Tail S-shaped, 40, 46 $\mu \mathrm{m}$ long, behind anus tail suddenly tapering off about 4 $\mu \mathrm{m}$, then again tapering sharply, terminal part cylindrical, terminus rounded. Tail with grouped caudal glands and terminal spinneret.

\section{Locality and plant association}

The species was recorded in the locality of Brodské in the south - western region of the country, in orographic unit Borská rovina, the plain of the River Morava at the Slovak 
- Czech border, in wet, heavy clay soil with Fluvisol soil type, regularly flooded forests with Fraxineto - Salicetum vegetation, undergrowth with Urtica dioica sporadically with Rubus idaeus.

The species is known from meadows at Oberseebach near Lake Lunz in Austria (Loof, 1993), from water of Baradla cave in Hungary (Andrássy, 1959a), from groundwater in Northern Italy (Andrássy, 1959b) and from a cave near Bergamo in Italy (Zullini, 1982). After consideration of Loof (1993) the species of Paramylonchulus californicus from Romania reported by Popovici (1990) is probably Mylonchulus andrassyi as well. This can be supported by a close concordance of the morphometrics of the Slovak specimens of $M$. andrassyi with those given from Romania.

\section{Tigronchoides ginglymodontus (Mulvey, 1961) Andrá- ssy, 1993 (Fig. 1. F - I)}

\section{Measurement and description}

Females (6): $\mathrm{L}=2.71 \mathrm{~mm}(2.43-2.96 \mathrm{~mm}) ; \mathrm{a}=27.6$ $(22.5-33.7) ; \mathrm{b}=4.4(4.1-4.8) ; \mathrm{c}=11.7(8.8-14.5) ; \mathrm{c}^{\prime}=$ $4.2(3.8-4.7) ; \mathrm{V}=67.6 \%(64.7-69.7 \%)$.

Males (5): $\mathrm{L}=2.62 \mathrm{~mm}(2.50-2.96 \mathrm{~mm}) ; \mathrm{a}=30.5(25.9-$ $37.8) ; \mathrm{b}=4.4(4.2-4.7) ; \mathrm{c}=15.7(13.8-16.6) ; \mathrm{c}^{\prime}=2.8$ $(2.5-3.3)$; spicules $=112 \mu \mathrm{m}(108-117 \mu \mathrm{m})$; supplements $=14(13-15)$; lateral pieces $18 \mu \mathrm{m}(16-20 \mu \mathrm{m})$.

The morphometrics of females and males agree closely with original description (Mulvey, 1961), with specimens from Yugoslavia (Barsi, 1991) and Bulgaria (Peneva et al., 1999). Female body ventrally arcuated after fixation. Lips sometimes flat, with distinct labial papillae, lip region slightly separated, $62-82 \mu \mathrm{m}$ wide and $16-22 \mu \mathrm{m}$ high. Buccal cavity roomy, barrel-shaped, $50-64 \mu \mathrm{m}$ long and $40-64 \mu \mathrm{m}$ wide, with three retrose teeth lying at anterior end of buccal cavity, dorsal teeth apex at $71-84 \%$ from the base of buccal cavity. Oesophagus $611-648 \mu \mathrm{m}$ long, oesophageal-intestinal junction tuberculate. Vulva with sclerotinised pieces, provided with $4-6$ anterior and posterior advulval papillae. Gonads amphidelphic. Body diameter at anal level of $52-60 \mu \mathrm{m}$. Tail $204-280 \mu \mathrm{m}$ long, elongate, conical, ventrally curved, tapering, tip rounded. Three caudal glands and spinneret present.

Males similar to females. In agreement with the description of males of the genus Tigronchoides published by Andrássy (1993) and Peneva et al. (1999), the teeth are situated more posterior in the buccal cavity - dorsal teeth is 64 $-71 \%$ from the base of the buccal cavity. Length of oesophagus $541-611 \mu \mathrm{m}$, tail length $160-192 \mu \mathrm{m}$.

Locality and plant association

In Slovakia, the species was observed at the same sampling site as Mylonchulus andrassyi, in mixed populations with this species.

According to Andrássy (1993) T. ginglymodontus is the most abundant species from the genus Tigronchoides, occurring in Poland, Romania, Serbia, Spain, Tadzhikistan, the U.S.A. and New Zealand. From Bulgaria, it was reported by Peneva et al. (1999). The species prefers terrestrial habitats, such as Fagetum and Quercetum forests, pasture, meadow, cultivated soil and soil with Vitis sp.

\section{Acknowledgements}

This study was supported by the Scientific Grant Agency VEGA No. 2/7191/27.

\section{References}

ANDRÁSSY, I. (1959a): Nematoden aus der Tropfsteinhöhle „Baradla“ bei Aggtelek (Ungarn), nebst einer Übersicht der bisher aus Höhlen bekannten Nematoden-Arten. Acta zool. Acad. Sci. hung., 4: $253-277$

ANDRÁsSY, I. (1959b): Nematoden aus der Psammon des Adige-Flusses. I. Mem. Mus. Civ. Stor. Natur. Verona, 7: $163-181$

ANDRÁSSY, I. (1992): A taxonomic survey of the family Mylonchulidae (Nematoda). Opusc. Zool. /Budapest/, 25: $11-35$

ANDRÁSSY, I. (1993): Taxonomic survey of the family Anatonchidae (Nematoda). Opusc. Zool. /Budapest/, 26: 9 $-52$

BARSI, L. (1991): First record of Anatonchus ginglymodontus Mulvey from Yugoslavia. Nematol. Medit., 19: 97 $-99$

Bongers, T. (2004): Fauna Europaea: Nematodes. Fauna Europaea version 1.1, http://www.faunaeur.org

Loof, P. A. A. (1993): Mylonchulus cavensis W. Schneider, 1940 (Nematoda: Mononchina). Nematologica, 39: $177-182$

Mulvey, R. H. (1961): The Mononchidae: A family of predaceous nematodes II. Genus Anatonchus (Enoplida: Mononchidae). Can. J. Zool., 39: 807 - 826

Mulvey, R. H. (1962): The Mononchidae: A family of predaceous nematodes II. Genus Miconchus (Enoplida: Mononchidae). Can. J. Zool., 40: 65-81

PeneVA, V., Neilson, R., NedelcheV, S. (1999): Mononchid nematodes from oak forests in Bulgaria. 1. The subfamily Anatonchinae Jairajpuri, 1969 with descriptions of Anatonchus genovi sp. n. and Tigronchoides quercus sp.n. Nematology, 1: 37 - 53

POPOVICI, I. (1990): Studies on Mononchida (Nemata) from Romania. Nematologica, 36, 2, 161-180

Zullini, A. (1982): Nematodi (Nematoda). - In: Guide per il riconoscimento delle specie animali delle acque interne Italiane, CNR AQ/1/190 